This is the version of the article accepted for publication in Energy Policy, 59. pp. 654-662, published by Elsevier. https:// doi.org/10.1016/j.enpol.2013.04.019

Re-use is subject to the publisher's terms and conditions

Accepted version downloaded from SOAS Research Online: http://eprints.soas.ac.uk/36247

\title{
The Governance of Clean Energy in India: the Clean Development Mechanism (CDM) and Domestic Energy Politics
}

Jon Phillips*, Peter Newell

* Corresponding Author: Mr Jon Phillips, Department of Geography, King's College London, Strand, London WC2R 2LS, UK; e: jonathan.phillips@kcl.ac.uk; t: +44 (0)20 7848 1054; f: +44 (0)20 78482287

Prof Peter Newell, Department of International Relations, School of Global Studies, University of Sussex, Brighton, BN1 9SN, UK.

Authors' post-print version. For the published version, see DOI:

http://dx.doi.org/10.1016/j.enpol.2013.04.019 


\begin{abstract}
This paper explores the ways in which clean energy is being governed in India. It does so in order to improve our understanding of the potential and limitations of carbon finance in supporting lower carbon energy transitions, and to strengthen our appreciation of the role of politics in enabling or frustrating such endeavors. In particular we emphasize the importance of politics and the nature of India's political economy in understanding the development of energy sources and technologies defined as 'clean' both through the United Nations Clean Development Mechanism (CDM) and leading international actors. By considering the broad range of institutions that exert formal and informal political influence over how the benefits and costs of the CDM are distributed, the paper highlights shortcomings in the narrow way in which CDM governance has been conceptualized to date. This approach goes beyond analysis of technocratic aspects of governance - often reduced to a set of institutional design issues - in order to appreciate the political nature of the trade-offs that characterize debates about India's energy future and the relations of power which will determine how, and on whose terms, they are resolved.
\end{abstract}




\section{Introduction}

All countries now face a range of energy challenges in promoting energy security, tackling energy poverty and de-carbonizing their economies to address climate change. But some countries face the dilemmas and conflicts between these objectives more acutely than others. In governance terms, India presents a particularly challenging case for domestic energy planners and international climate policy advocates alike. India is the fifth largest greenhouse gas emitter in the world and projected to become the third largest emitter by 2015 (IEA 2007). The majority of India's emissions are produced by the energy sector (MoEF 2010), yet the carbon intensity of India's economy is around half that of China and lower than the US. Moreover, the country's low per capita emissions are projected to remain below the 2004 world average up to 2031 (MoEF 2009a). Indeed, while India is a major global producer and consumer of energy, it also faces huge suppressed demand for energy, with more than 400 million people lacking access to electricity and 700 million people depending on biomass for cooking fuel (IEA 2010).

Yet the political thrust of India's drive for 'energy independency' (Planning Commission 2006) is provided by the current energy supply-demand gaps and the huge increase in primary energy consumption required to meet economic growth targets of 8-10 per cent in the medium term. Reconciling climate change concerns with India's economic growth will clearly require a significant transformation of the country's energy supply. As India’s Integrated Energy Policy notes: ‘even if India somehow succeeds in raising the contribution of renewable energy by over 40 times by $2031-32 \ldots$ the contribution of renewables to our energy mix will not go beyond 
$5.6 \%$ of total energy required in 2031-32' (Planning Commission 2006: 82). The current installed capacity for grid-interactive renewable energy is over $26 \mathrm{GW}$, with government targets aiming to install an additional 74GW by 2022 (MNRE 2010; MNRE 2013). However, while India has put in place policies for scaling up 'clean energy ${ }^{1}$ power generation, there remains huge potential to scale up the use of renewable sources to meet both on- and off-grid energy needs and replace conventional energy sources.

It is against this background that we situate our analysis of the politics and governance of clean energy in India and in particular the present and potential role of the Clean Development Mechanism (CDM), which currently constitutes the largest source of mitigation finance to the developing world (World Bank 2009). India has been one of the biggest recipients of CDM finance to date, hosting over 850 registered projects (a fifth of the global total), but has faced criticism with respect to both dubious additionality of greenhouse gas emission reductions and weak contributions to sustainable development, the second objective that CDM projects are meant to achieve. Existing literature on the CDM has addressed issues such as the performance of specific technologies (e.g. Purohit \& Michaelowa 2008), forms of technology transfer (Dechezleprêtre et al. 2008) and assessments of the sustainable development outcomes of projects (Castro \& Benecke 2008). Other studies have considered particular characteristics of the Indian carbon market, including the prominence of unilateral projects (Krey 2005; Michaelowa 2007) or the functioning of India's Designated National Authority (DNA) (Ganapati \& Lui 2009). More directly relevant to the broad governance approach taken in this paper, 
some attention has also been directed to considering Indian 'carbon governance' in general (Benecke 2009).

Less attention has been focused, however, on building a detailed understanding of the different levels of governance and the coalitions of actors and institutions which, we argue, influence the outcomes of India's efforts to promote clean energy. Conceiving of clean energy governance in this broad manner means situating CDM projects and procedures within a wider set of political and economic power relations in the energy sector. This helps to advance an understanding of governance in practice: the role of power and politics in shaping clean energy governance, from global to local level, and across the spectrum of public and private initiatives and decision-making processes in India. To understand the exercise of power in practice beyond the formal division of responsibilities for energy policy means discussing the factors that impact upon actual decision-making and the outcomes of battles over bureaucratic authority, access to finance, or the balance of power between state and market actors. We therefore present an analysis informed by interviews with carbon market actors in India - government officials, market actors and their critics - as well us with many of the key regional and international institutions working on these issues in India. ${ }^{2}$

The paper begins by outlining the regional and global influences that shape India's clean energy sector: the governance of clean energy 'from above'. It then turns to the governance of clean energy 'from below': the national politics of clean energy and the domestic power struggles in which international instruments such as the CDM become embroiled, and which they must engage if they are to make a significant 
contribution to realizing India's clean energy goals. We then outline areas of the 'ungovernance' of clean energy and locate this within the wider political economy of energy in India before offering some concluding thoughts.

Providing an analysis of the politics underpinning governance arrangements in the energy sector means exploring the power of competing interest groups - those both directly involved in carbon markets and those influencing energy policy more broadly - that can resist, block or steer the CDM and its governance in particular directions. Scholars of energy transitions have referred to the alignments of actors and institutions with a stake in different energy futures in terms of 'incumbent' regimes organized around predominant socio-technical systems (such as fossil fuels) and 'niches' (such as particular types of renewable energy), which compete for resources and political support from state, private and other actors that populate the broader 'landscape' that impinges upon particular socio-technical systems (Geels 2005; Verbong \& Loorbach 2012). Scholars of 'transitions management', in particular, have called for approaches to move beyond a focus on institutional design and management issues and to address more fully the politics and non-politics of transitions (Scarse and Smith 2009; Meadowcroft 2009). This line of critique resonates with our attempt to go beyond conventional analysis of CDM governance as specific issues of institutional design, to the neglect of underlying questions of politics and power, and how these shape outcomes. We draw on the following notions of power to develop such an analysis of the role of the CDM in India's energy politics: (i) structural and material power, which derives from control of resources, finance and production, but which might also extend to technological power (Falkner 2008). In this context, these forms of power apply to the corporations 
whose production CDM finance seeks to shape; to technology providers; and to the international institutions that administer climate funds; (ii) bureaucratic and organizational power, which derives from access to and control over key sites of decision-making and here refers to the distribution of power and authority across state agencies with responsibilities for energy and climate change; and finally (iii) discursive power, or the power to shape framings of issues and the production of narratives, which is employed by a range of actors in making the case for and against the benefits brought about by the CDM and derives from access to media and key communication channels ( $c f$. Levy \& Newell 2005; Fuchs 2007). We describe below how these forms of power are mobilized to produce as well as frustrate change, and to maintain the power of incumbent actors, as we explore in the final section on the 'un-governance' of clean development.

\section{Clean Energy Governance from Above}

This section consider actors and institutions beyond India's borders that have a role in governing clean energy in India and the extent and ways in which these forms of 'governance from above' shape and constrain India's policy making process and policy autonomy (Newell et al. 2009). This resonates with what would be called 'landscape' factors in the transitions literature mentioned above.

Within the formal channels of the UNFCCC, India has been a leading voice of the G77+ China group in emphasizing that industrialized countries bear the historical responsibility for climate change and are obliged to act first to reduce their emissions and compensate countries such as India with finance for mitigation and adaptation 
measures (Michel \& Pandya 2009; Michealowa \& Michaelowa 2011). This position is reflected in the country's approach to the CDM and to Nationally Appropriate Mitigation Actions (NAMAs), which has sought to align carbon finance with national energy and industrial priorities rather than allow it to be used as a means of committing India to emissions reductions. For example, India has pushed for expansion of the project-based CDM to include large hydro power projects, nuclear power and forestry; for the removal of requirements to demonstrate the 'additionality' of CDM finance for renewable energy projects; and for the use of public climate finance to meet the continued shortfall in demand for carbon credits in developed countries (MoEF 2009b).

Yet while increasing international pressure on India has not been the primary driver of governmental action on clean energy, it has contributed to the formation of a powerful narrative around climate co-benefits for domestic actions de-linked from global commitments, behind which government, business and civil society interests have largely united (Dubash 2009). Through the CDM, India is engaging with international climate finance in ways that are geared towards aligning the scale up of clean energy with India's domestic framing of climate policy. India's Ministry of New and Renewable Energy has stated for example that adequate international finance through the CDM, NAMAs or other sources could double the ministry's current renewable energy targets (Gupta 2010).

Outside the intergovernmental negotiations on climate finance, India's prosperous CDM market has made the country a site of significant flows of global public finance for energy. India has been the subject of ongoing capacity building programs 
to develop its CDM governance from the United Nations Development Programme (UNDP), Asian Development Bank (ADB) and German Technical Cooperation (GTZ, now GIZ), dating back to 2003 in the case of GIZ and 1999 in the case of a US capacity building programme (GTZ 2006). These programmes helped to institutionalize the CDM, address apparent market failures, and build the capacity of states, municipalities and private companies in developing projects, and are acknowledged by the Indian government to have been instrumental in initiating interest in the CDM beyond the DNA. ${ }^{3}$ Through this role, these institutions have steered the CDM in certain directions by addressing governance deficits in line with their respective expertise and interests, such as ADB efforts to increase the participation of the domestic finance sector and support projects within its financing rules; or GIZ actions to support projects with enhanced sustainable development benefits and to facilitate the sale of credits to German buyers. ${ }^{4}$

The CDM is also supported in India through carbon funds operated for client companies by the ADB and International Finance Corporation (IFC), (the private sector lending arm of the World Bank Group). These funds co-finance projects upfront in exchange for a portion of the expected CERs (Certified Emissions Reductions) generated, performing market governance functions by providing price transparency and transferring the risk of non-delivery of credits away from buyers. Not all such efforts to shape the operation of carbon markets in India have been welcomed, however. The first of the World Bank's carbon funds, the Prototype Carbon Fund (PCF), for example, received criticism for offering poor deals on the purchase of CERS in India and administering an overly-bureaucratic process. ${ }^{5}$ 
Despite the material power wielded by landscape actors through their control over clean energy finance, their power has been contested. India has sought to assert its policy autonomy in setting the terms of climate finance flows for energy by initially rejecting potential funds from the World Bank's Climate Investment Funds, despite the country's status as a 'prominent potential client' (Sethi 2008). Setting its preferred terms, India has since submitted a draft investment plan to the Bank's Clean Technology Fund in 2011 (CIF 2011), prioritizing investments in, among other projects, a policy development loan for politically contentious changes to the streamlining of hydropower approval processes in Himachal Pradesh, where local citizens have expressed opposition to existing plans.

Beyond carbon markets and climate finance, MDBs remain influential in shaping India's energy sector, both through the loans they extend and through the transmission of global norms of finance allocation, management and ownership; creating or altering political relationships of power between the recipients and providers of capital. Financial crises and calls for climate-sensitive energy financing have provided MDBs with strategic opportunities to re-engage with energy financing in Asia, where industrializing countries otherwise become less dependent on MDBs to meet project financing requirements. Within this context, MDBs have begun to increase the proportion of their core concessional and private sector finance for clean energy projects (BNEF 2010).

However, alongside its support for 'clean' energy, public energy finance to India continues to provide significant financing for fossil fuel exploitation. For example, the ADB and IFC are both part-financing the first of India's Ultra Mega Power 
projects (UMPPs), the $\$ 4.1$ billion, 4000MW Mundra coal power plant project in Gujarat, ${ }^{6}$ citing the use of more efficient supercritical technology as a key investment criterion. The CDM Executive Board rejected Tata's Mundra project on the grounds of additionality, but has approved a number of similar projects such as Reliance Power's UMPPs at Sasan and Krishnapatnam (Fisher 2009; IFC 2008), drawing criticism about methodological weaknesses in assessment and raising broader issues about the use of CDM finance for minor improvements in coal power plant efficiency (Lazarus \& Chandler 2011). The effect of such support from the CDM and World Bank is to entrench the bureaucratic power of the incumbent coal regime in India centered in the Ministries of Power and Coal at the expense of the Ministry of New and Renewable Energy (MNRE) which aims instead to lever international finance to shift the country's energy fix in favour of 'clean' energy as described above.

Despite the existence then of a broad range of international initiatives aimed at promoting clean energy, levels of international finance for clean energy remain inadequate compared to the scale of the energy challenge in India and contradictory in their effects with simultaneous support for fossil fuel and renewable energy development. We will now explore how the impact and effectiveness of 'Clean energy governance from above' and its ability to reconfigure energy governance in India is ultimately affected by the national and sub-national political processes that mediate and shape it.

\section{Clean Energy Governance from Below: The National Governance of Clean Energy in India}


India's system of national governance has had a decisive influence over the direction of clean energy development and over the role of the CDM in supporting clean energy in the country. The growth of renewable energy in India has been generated largely by the private sector, not through CDM finance, but by a regulatory framework and series of incentives created by the state positioning itself as the enabler of private investment. India's Five Year Plans and various policy 'missions' such as the National Solar Mission are based on a model of state-led development that dates from the era of Nehru. The majority of corporate finance has thus far focused on mature markets in large scale wind installations and commercially viable hydro projects (MNRE 2010), with the wind industry benefiting from a regulatory framework provided by central government and a series of financial and fiscal incentives provided by states, including feed-in-tariffs, accelerated depreciation, tax exemptions and low interest loans (Rao \& Kishore 2009).

The result is that for several successful sectors of clean energy technology mature markets and significant capabilities exist (Lema \& Lema 2012), such that renewable energy projects in India are increasingly attractive to investors on a risk return basis, independent of carbon finance. Contrary to the intended role of CDM finance as a driver of investment in renewable energy, the range of incentives provided by the Indian state, central planning and enthusiasm for domestic trading initiatives ${ }^{7}$ mean that the promise of CDM revenue provides the 'icing on the cake' or a 'psychological boost' as project developers put it, ${ }^{8}$ but rarely drives investment decisions. Many critics of the CDM in India have referred to a US Consulate cable leaked in 2011 as confirmation of a widely held belief that the process of 
additionality calculation in practice involves more complex calculations of financial risk and return than belies the formal process (Schiermeier 2011). Given the long lead times inherent in the international CDM approval system, project developers feel that relying on CDM finance represents a highly risky business strategy. Rather, the suggestion of carbon market actors in India is that government policies to facilitate the uptake of renewable energy mean that, in practice, the CDM has come to play an additional, supplementary role in incentivizing projects and shaping their viability, rather than a decisive one.

We find a mixture of public and private power at work here consistent with other work on the CDM's 'hybrid' governance model (Streck 2004). While the CDM Executive Board ultimately approves projects and issues credits based on judgments about the additionality of projects, project developers and their consultants exercise a degree of power about which projects are selected, and whether they are considered worthy of support through their judgments about the financial viability of projects. These include the preparation of distinct cases of financial viability for domestic and international sources of finance. ${ }^{9}$ The private sector's assessments of India's attractiveness for renewable energy investment also wield considerable discursive power, constructing India as a positive place to invest and in doing so shaping flows of finance. For example, when HSBC greets the planned release of a report outlining how India plans to meet its energy intensity target by 'upgrad[ing] the country's climate strategy rating to positive' (Knight et al. 2010), it governs the market that it describes by shaping investor perceptions and ultimately the distribution of finance. The power of business groups also enters the picture as initiators and shapers of a particular type of 'open' CDM governance. Lobbying by Indian businesses was 
important in shifting the Indian government position on market mechanisms to one that embraced the prospect of the CDM and led to the early establishment of the DNA in 2003 (Michaelowa \& Michaelowa 2011). A variety of international consultants have served as market enablers by utilizing existing networks of clients and partnering with local technical consultants to promote project development and influence the direction of early CDM investment towards particular sectors (Pulver $\&$ Benny 2010). In the case of Price waterhouse Coopers (PwC), they also stand accused of being implicated in the promotion of non-additional projects (Michaelwa $\&$ Purohit 2007), undermining the integrity of emission reductions. Industry lobbies such as the Confederation of Indian Industry (CII) and the Federation of Indian Chambers of Commerce and Industry (FICCI) have also played a part as market facilitators by generating demand and raising awareness of CDM opportunities for Indian companies.

Private actors also enact CDM governance through the less formal, everyday acts of governance performed through the seemingly technocratic but inherently political exercises of auditing, monitoring and accounting for emissions reductions and sustainable development benefits (Lovell \& MacKenzie 2011). The private governance functions performed by Designated Operational Entities (DOEs) have received a great deal of attention in India, due to both the high degree of formal authority they are delegated (Green 2008) and the common perception that their poor performance has caused delays in project validation and emissions auditing. Due in part to capacity constraints, the DNA is heavily reliant on the assessments of DOEs. This is problematic in light of claims that certain DOEs are reluctant to visit the sites of projects to validate stakeholder consultations, which in some cases have presented 
duplicate 'cut and paste' comments in PDDs for separate projects (CSE 2005). Hence while efforts to make information about projects held in PDDs more publicly available are important, they do not detract from the potential for serious shortcomings in the quality and reliability of the information contained in them. Nor do they compensate for poorly conducted consultation processes about the impact of projects, as we discuss below. The technical expertise required to make sense of the documents, produced not for public consumption, but to seek approval from governments and the EB, means they are often in reality inaccessible or intelligible to communities expected to host projects.

Beyond the governance of claimed emissions reductions, what then is the role of the Indian government in overseeing the delivery of the other aim of the CDM, to bring sustainable development benefits? The state in India has played a notably less active role in governing and steering the CDM than in other areas of the energy economy. The DNA is responsible for ensuring that sustainable development benefits are integrated into the design of each CDM project. Pressure over the high rejection rate of Indian projects by the Executive Board has reportedly led to a tightening of the host country approval process regarding the financial 'additionality' of projects (Benecke 2009) but to date the Government of India has opted not to enforce 'hard' regulations such as taxation regimes, a floor price for CERs, or differential fees in line with priority sectors. Indeed, the Indian DNA's broad sustainable development criteria and decision-making in practice appear geared more towards ensuring a smooth domestic approval process for project developers than ensuring the integrity of sustainable development outcomes. ${ }^{10}$ Late in the day, in 2012, the Indian DNA dictated that large scale projects should commit to sharing 2 per cent of CER revenue 
with local communities, partly in response to sustained criticism of the contribution of CDM projects to sustainable development,. While this makes a (small) contribution to the redistribution of benefits deriving from CDM projects, sharing revenue on this scale is unlikely to shift the calculus of investors in CDM projects about the level of benefits they are expected to provide.

Thus, India currently presents more of a case of market-enabling governance for, rather than governance of the carbon market. Studies of the perspectives of companies on the CDM approval process for example indicate that firms perceive there to be a low risk of project rejection by the Indian DNA (Hultman et al. 2012), reinforcing concerns that project approval proceeds with little scrutiny and few checks about whether CDM projects are likely to deliver claimed sustainable development benefits or avoid harm for local stakeholders. ${ }^{11}$ Critics have claimed that the failure of governance in relation to sustainable development has resulted in negative social and environmental effects associated with particular projects including detrimental health and environmental effects, and loss of livelihoods (Böhm \& Dabhi 2009). Likewise, domestic industrial projects that receive support from MDBs have provided focal points for activists documenting the shortfalls against the environmental and social investment guidelines of MDBs. Activists have used global networks and online media to expose cases of alleged 'carbon fraud' (dubious project additionality) and 'climate colonialism', where people are dispossessed of their land by foreign actors. In governance terms the effect of this watchdog activism is to force responses from the DNA and from project developers, a small proportion of whom in India have sought to establish the credibility of their projects by seeking certification from the Gold Standard Foundation. The Gold 
Standard provides an extra set of process checks and requirements on the fulfillment of sustainable development criteria, though the associated transaction costs have been considered too great for some project developers even where they consider themselves compliant with Gold Standard norms. ${ }^{12}$

\section{The Role of States in Clean Energy Governance}

Given the light touch steering role adopted by the DNA, it does not currently have the decisive role in governing the CDM within India envisaged by formal CDM governance structures. Governance at state and local level also has a key role to play in determining the extent to which benefits flow from the CDM. This is reflected in the uneven distribution of CDM projects and revenue within India, where Tamil Nadu, Maharashtra, Karnataka and Rajastan each have over 200 projects at validation stage, while several other states host no projects at all (Fenhann 2012). While economically prosperous states have generally seen greater CDM investment than poorer ones (Sirohi 2007), 'good governance' also appears important since these same states are those that generate confidence among investors based on perceived respect for the rule of law and property rights and having an attractive investment climate.

Several states that have attracted CDM projects have also created single window clearance systems and CDM promotional centers in order to create an enabling policy environment. In other states, CERS were shared with the electricity grid operators that transmit the power generated by independent power producers, reducing the financial incentive for project developers. ${ }^{13}$ However, considering that 
$\mathrm{CDM}$ revenue alone is rarely if ever sufficient to initiate project development, it is perhaps unsurprising that the biggest winners have been states such as Gujarat and Tamil Nadu with established industrial sectors and attractive policies and governance arrangements to facilitate private investment in energy (Benecke 2010). In contrast, there has been a perception in some states that, as a market mechanism, the CDM 'would be taken care of by industry'. ${ }^{14}$ Many states lack the capacity to promote and process CDM projects. The experience of state bureaucrats suggests that the promotion of renewable energy and the CDM at state level is often driven by motivated individuals rather than institutionalized processes. ${ }^{15}$ Indeed, there is great variability in institutional capacity across states, as well as between the actual roles and functions that analogous state authorities perform. From the perspective of project developers, the division of responsibility for approving and overseeing projects is not always clear. ${ }^{16}$ Presented with incomplete information and uncertainty, developers' perceptions of effective governance can therefore also be important in directing the geographical distribution of investment.

\section{Local Governance}

Beyond the national and state structures that direct CDM investment, the distribution of sustainable development benefits among citizens is mediated by local institutions, in so far as CDM projects (like other proposed industrial development projects) are required to hold local consultations with affected stakeholders prior to implementation. The distribution of benefits (e.g. job creation, access to technology, or improvements in local air quality) is often at the heart of discussions about proposed projects. Local governance is decisive in determining who gains from 
particular projects, and the extent to which certain projects are endorsed or resisted at the local level. Who gains from particular projects is shaped by the nature of consultation processes, the capacity of local institutions to engage with them, their political power to (re)shape the design of projects (since project developers have to provide an account of how they have addressed any issues raised during the consultations), and whose interests they pursue in such spaces of participation.

Political decentralization in India has opened space for local institutions to play a greater role in mediating between project developers, the state and citizens, providing a means for people to participate in policy making through institutions with the sort of permanent and visible presence in local political life that cannot be achieved by central or state bodies. However, precisely because the Panchayat Raj system of local institutions has been delegated greater responsibility for running a range of local affairs, they often have little capacity to take on the additional responsibility for oversight of CDM consultations. For example, quarterly meetings of the Gram Sabha ${ }^{17}$ mean that discussion can often only focus on a single issue, such as the government's rural employment guarantee scheme. Given the limited regulatory oversight of the claimed sustainable development benefits by the DNA, it is perhaps not surprising that reports of lax procedures on the part of project developers in engaging local stakeholders are commonplace. These include one-off invitations to consultation meetings issued in English language newspapers, in areas where the language is rarely spoken or a significant proportion of residents are not literate. 
Moreover, local institutions are not immune to corruption or capture of consultative processes by local elites and often have weak systems of accountability in place for the management of revenue and project benefits. For example, the wind turbine producer Suzlon has made allegations of corruption among state and local officials while attempting to secure the necessary community approval for India's largest wind farm. ${ }^{18}$ However, the time and effort required to initiate projects with strong deliberative decision making and cross-community support can result in prohibitively high transaction costs in the eyes of CDM investors and project developers, limiting the prospects for demand-led projects at community scale. While some of these issues stem from the fundamental design of the CDM, given its process requirements, governance by India's national, state and local institutions significantly shapes whether CDM projects produce the social and development benefits promised and where and to whom the benefits are distributed.

A series of interventions from public and private actors have attempted to address some of the governance challenges outlined above by promoting a stable investment environment through improvements in the rule of law and increased institutional capacity and coordination. Promoting the 'good governance' of CDM (Chapman 2011) is important given that lack of capacity presents a significant constraint for the DNA, which is sometimes required to review fifty to sixty PDDs in each monthly sitting; and for the ministries on the approval committee, which typically have little technical knowledge of the CDM itself. ${ }^{19}$ These programs are well supported by international donors, particularly those with interests in market-led development and the success of the CDM as a carbon offset mechanism. GIZ, for example, has attempted to improve the administrative performance of the DNA by introducing a 
paperless application process and has responded to criticisms of consultation procedures by collecting photo and video evidence of community participation in projects that it supports. This constitutes an improvement on the short descriptions of consultation processes provided in PDDs which the EB requires to be made publicly available. However, while these efforts address the efficiency and effectiveness of core CDM procedures, they fail to locate the distribution of CDM benefits and costs in the broader context of politics and the relations of power that influence the CDM and that we describe below.

\section{The Political Economy of Clean Energy in India}

In this section we discuss how the national governance of the CDM and clean energy is profoundly affected by the broader political economy of energy in India in which powerful coalitions of interests seek to shape India's energy future and - directly and indirectly - the role of the CDM within it. Although ongoing market-based reforms of energy governance are planned in India, the energy sector as a whole retains a high level of state influence (Joseph 2010). As described above, with regard to carbon markets and renewable energy the most significant role of the state has been in setting enabling policies, rules and procedures for private sector finance and technology development. But a broader set of political dynamics within the state impact upon these policy areas. Considering renewable energy specifically, new policy initiatives such as the Renewable Energy Certificate Scheme may continue to be affected by governance issues experienced in the enforcement of Renewable Purchase Obligations for State Electricity Regulatory Commissions (SERCs), where a combination of turf wars, lack of administrative competence, capacity constraints, 
and entrenched political interests have resulted in poor implementation in several states and produced unstable and unpredictable policies (ADB 2008). In this context, navigating CDM governance presents just one of a set of political challenges for investors affected by policies on land, state level clearances, renewable energy tariffs, and grid connections.

At the local level too, CDM financing enters India's national and local energy policy landscape in the context of ongoing discontent with consultative and participatory processes around development and infrastructure projects. The Environmental Impact Assessment (EIA) process has been repeatedly criticized for failing to allow involvement of affected citizens in the scoping stage of project design, opting instead for public hearings based on the completed EIA, a similar process to the majority of CDM project consultations (Mahalingham et al. 2006). Although policies such as the Electricity Act of 2003 have allowed for greater opportunities for civil society input to policy, the dynamics of the power sector can prove to be complex and the range of organizations able to engage with the social and environmental assessments of electricity policies on behalf of civil society is limited and uneven (Mahalingham et al. 2006). Likewise, some local NGOs and civil society organizations such as Carbon Market Watch are actively engaged in monitoring selected CDM projects. But their capacity to critically monitor the environmental and social planning of India's large number of CDM projects is limited. Hence while the democratic space for local and national engagement with the $\mathrm{CDM}$ is greater in India than other major host countries such as China, accountability cannot be provided through these institutions alone in a large, diffuse and complex market, such as the CDM in India. In the absence of mechanisms to monitor project outcomes, assumptions regarding the 
compensating presence of an engaged and well-resourced civil society are problematic.

These and other features of India's contemporary political economy shape how and where CDM investment goes and who benefits at a variety of scales. In the short term, many of the most accessible sites for on-shore wind projects in India, encouraged by the sorts of policies we have analyzed above, are situated in forested or 'tribal' areas. Land acquisition is a contentious issue, referred to by some in the investment community as a 'long, tedious and often opaque business' underpinned by 'a huge amount of murky political economy' (Kadakia \& Acharya 2010: 15). Indeed, many conventional energy generation projects are said to have been delayed on these grounds, making renewable energy a particularly attractive political option where land is available and the transfer of its use is less contentious, such as for solar power installations in desert states (MNRE 2010). Yet as Narain (2011) notes, strong institutions and procedures for meaningful public participation help to create a credible governance process that mitigates the risks faced by investors. A constructive approach may call for a greater consideration of procedural issues in CDM and energy policy-making, and recognition of their importance in determining for whom energy policy is designed and to whom the benefits and potential tradeoffs of energy development are distributed.

Indeed, creating an enabling environment for renewable energy is deeply politicized when considering the potential trade-offs of providing the 'long, loud and legal' market signals demanded by investors (Hamilton 2009). Among current government initiatives, the National Solar Mission creates perhaps the clearest example of 
political challenges in constructing long term policies for clean energy, and the challenges of maximizing the value of additional international climate finance. The Solar Mission is contentious due to its costs, as it proposes to step outside of the dominant co-benefits framing of clean energy in India, at least in the short to medium term. Questions of who will bear the cost of solar electricity tariffs and decentralized energy distribution, and how the costs will be managed, are foremost in determining the short and long term success of a policy that could put India in a strong political position with respect to clean energy technology manufacturing and distribution, ${ }^{20}$ notwithstanding the tensions this has generated with the US at the World Trade Organization (Politi 2013). The governance of this rapidly emerging policy area will be critical to determining in which ways climate finance, including the CDM, will contribute to its realization or increased ambition. The role of the CDM would be quite different for example depending on whether it continues to provide additional finance or solar hardware, or whether it is used to develop the foundations of technological skills, knowledge and capabilities among firms and communities. While the CDM is not designed or positioned to transform domestic political interests, the political economy of energy in India will likely shape how the limited and variable flows of CDM finance will need to be governed in order to engage national processes and existing political interests, if it is to have a transformative effect on the adoption of renewable energy in the Indian context.

The 'Un-governance' of Clean Development

We have highlighted above the international, national and sub-national level institutions and actors that - in various modes and capacities - govern the role that 
the CDM and clean energy have come to play in expanding India's energy generation capacity. Yet it is as important to consider the $u n$-governance of clean energy in India as it is to assess the institutions that assume formal responsibility for governing clean energy. We use the term 'un-governance' to refer to areas of deliberate and active neglect, where power is exercised to ensure action is not taken and prevailing material and bureaucratic interests protected (cf. Crenson 1971). In this context it entails recognition that the actors and institutions with primary responsibility for clean energy development are rarely those actors which yield most power over the course of energy policy development. It manifests itself in the way the incumbent regime, largely centered around the continued use of fossil fuels, accommodates niche initiatives on clean energy without reducing its position of power within India's energy regime.

Instances of un-governance or deliberate neglect become most apparent in cases where plans for renewable energy generation or enhanced environmental concern begin to imply limits on fossil energy development. This tends to occur only in the rare cases when clean energy measures are positioned outside of the dominant discursive framing of clean energy 'co-benefits' in India. Hence, while India's much feted MNRE is the only ministry in the world dedicated solely to renewable energy and has seen large budgetary increases over recent years (Planning Commission 2010), the financial allocation for renewable energy remains small in comparison to total energy allocation which continues to favor the incumbent coal regime. Moreover, the decision to form a National Clean Energy Fund from a tax on domestic and imported coal ${ }^{21}$, which might appear as a loss for coal interests, has been considered by some observers to be politically feasible only because the 
revenue collected is essentially small enough to constitute no real threat to the coal industry. $^{22}$

The Ministries of Power and Coal command much greater financial resources and political power within government than either MNRE or MoEF. When former Minister of Environment and Forests Jairam Ramesh began to enforce previously perfunctory procedures on environmental clearances for proposed industrial and energy developments, it aroused significant disquiet among more powerful ministries involved in energy policy who characterized his position as 'anti-business' (Ramesh 2010). While staff in MNRE in particular are keen to utilize the CDM to support greater ambition in the development of policies such as the National Solar Mission, ${ }^{23}$ the CDM does not garner significant interest from the Ministry of Power (MoP) despite the significant proportion of India's CERs generated from India's capital intensive large coal power plants. ${ }^{24}$ Indeed, the prominent industrial developers of such projects are largely those with the capacity to engage with CDM procedures and accounting exercises, such that state steering or sectoral prioritization of the CDM may appear of little relevance to powerful ministries such as the MoP. Any potential prioritization of particular energy service needs for poverty alleviation, or particular technologies and associated knowledge that might strengthen Indian industry expertise would, in effect, challenge this ability of existing political interests to benefit from climate finance. And whilst the MNRE may provide avenues of stakeholder engagement (however imperfect) for promoting low carbon, pro-poor energy technologies, there is no evidence to suggest that the Ministry of Power is obliged to include MNRE within its decision making on policies that affect the power sector (Mahalingham et al., 2006). 
In light of the differential power among energy ministries, India's Planning Commission - the coordinating body for Five Year Plans and 'holistic' energy planning exercises such as the Integrated Energy Policy - has a potentially important role in steering Indian energy policies towards simultaneously addressing climate change and energy poverty concerns. For example, in preparation for the country's next Five Year Plan (2012-2017), the Planning Commission was tasked with preparing a roadmap for inclusive low carbon growth, including how the government may meet its carbon intensity target. Yet the Planning Commission is not deemed to have the authority nor the mechanisms to enforce change in the relevant ministries, or to ensure coherence between them (Dubash 2011). Its ability to unsettle existing power relations remains in doubt therefore. Alongside national policies that specifically address clean energy growth, the nature of these power relations in the energy sector in India play a critical role in determining how India will govern clean energy and how carbon and climate finance will be received into the political economy of energy in India over the coming years.

\section{Conclusion}

Our analysis has sought to highlight the role of politics, power and political economy in understanding how and whether schemes such as the CDM are capable of producing social and development benefits while levering additional sources of clean energy finance in India. In so doing it has added to, and gone beyond, an understanding of a narrower set of state-based governance factors such as capacity, efficiency and accountability explored by existing studies. Although some of the 
governance factors that influence the performance of the CDM are determined by the structural design of the mechanism itself, we have argued that in the case of India, 'governance from below' by a multitude of actors and institutions at national, state and local level shapes how and whether benefits flow from the CDM to their intended beneficiaries. Future interventions, if they are to be effective in producing large-scale change, need to understand, engage and ultimately unsettle this broader political terrain.

The approach to examining governance presented here has included the governing roles of a range of actors across the public-private spectrum; across scales from village institutions to global institutions; and including both formal institutions and the informal practices of day to day governance. Using this wide definition, we have considered how the power and influence over energy policy-making and administrative procedures concerning the CDM has impacted upon the creation and design of CDM governance, who influences decisions at national and local levels, and therefore who benefits from clean energy financing. These processes in turn shape how significant a role 'clean energy' initiatives including the CDM come to play in India's energy regime. Far from being technocratic or purely managerial issues (Bhattacharyya 2010), decision-making about the bankability and financial viability of projects, the degree of integration of clean energy initiatives within overall state energy strategies, and decisions about who has the right to participate in decisions about projects and policy, are aspects of governance that are highly political by virtue of their importance in directing and shaping the flows of international and domestic clean energy finance and the associated benefits and trade-offs. This, we argue, is critical for understanding the 'governance in practice' 
of market-based mechanisms such as the CDM. Here in particular, the 'ungovernance' of clean energy often has significant impacts on whether or not clean energy goals are achieved: the actors and policy processes that are not typically perceived as the subjects of clean energy governance but which can undermine the effect of clean energy policies, through ongoing investments in fossil fuels and directing of flows of foreign finance towards that end.

India's early state-led growth in clean energy technologies has largely dictated the role that the CDM has come to play in the country. In this regard, the extent to which the CDM can fulfill its dual aims of creating sustainable development benefits alongside emissions reductions is dependent on the broader institutional environment and political economy of energy policy and the relations of power which characterize the domestic energy sector. In turn, we argue that this implies an appreciation of how the influence and power of 'incumbent' versus 'niche' actors, for example, shapes the extent to which national policy is steered towards particular public goals and reflects certain interests over others in attempts to simultaneously address climate change, energy poverty and energy security. We have argued here for greater appreciation in scholarship and policy making of the role that national and local energy governance and politics plays in determining whether the CDM becomes aligned with domestic clean energy politics and, ultimately, in shaping its prospects for contributing to low carbon energy transitions in industrializing countries such as India. 


\section{References}

ADB, 2008. Energy Infrastructure: Priorities, Constraints, and Strategies for India. Oxford University Press India, Delhi.

Bhattacharyya, S.C., 2010. Shaping a sustainable energy future for India:

Management challenges. Energy Policy, 38(8), 4173-4185.

Benecke, G., 2009. Varieties of carbon governance: Taking stock of the local carbon market in India. Journal of Environment and Development, 18(4), 346-370.

Benecke, G., 2010. Stakeholder networks in carbon governance: The role of statemarket relations in the Indian renewable energy sector. Working Paper 007, The Governance of Clean Development Working Paper Series. School of International Development, University of East Anglia, UK.

BNEF [Bloomberg New Energy Finance], 2010. Weathering the Storm: Public funding for low-carbon energy in the post financial crisis era. London, BNEF.

Böhm, S., Dabhi, S., (eds) 2009. Upsetting the Offset: The Political Economy of Carbon Markets. Mayfly Books, Colchester.

Castro, P., Benecke, G., 2008. Empirical Analysis of Performance of CDM Projects:

Case Study India. Climate Strategies, Cambridge

Chapman, S., 2011. Assessing 'Good' carbon governance in India. Good Carbon Governance Working Paper 4. Cambridge Centre for Climate Change Mitigation Research, Cambridge

CIF [Climate Investment Funds], 2011. CTF Investment Plan for India. Meeting of the CTF Trust Fund Committee, Washington, D.C. CTF/TFC.8/4.

Crenson, M., 1971. The Un-Politics of Air Pollution. Baltimore, Johns Hopkins University Press. 
CSE, 2005. Newest Biggest Deal. Down to Earth, 15 Nov.

Dechezleprêtre, A., Glachant, M., Ménière, Y., 2009. Technology transfer by CDM projects: A comparison of Brazil, China, India and Mexico. Energy Policy, $37(2), 703-711$.

Dubash, N., 2009. Toward a progressive Indian and global climate politics. Centre for Policy Research Climate Initiative Working Paper 2009/1, September. Centre for Policy Research, Delhi.

Dubash, N., 2011. From norm taker to norm maker? Indian energy governance in global context. Global Policy, 2(3), Special Issue

Falkner, R., 2008. Business Power and Conflict in International Politics. Palgrave, Basingstoke

Fenhann, J., 2012. CDM Project Distribution Within Host Countries by Region and Type. UNEP Risø Centre, Roskilde. Available at: www.cdmpipeline.org, accessed 10 September 2012.

Fisher, K., 2009. Carbon offsets \& climate finance in India: The corporate-driven climate 'solutions' of the World Bank, Asian Development Bank and United Nations. Focus on the Global South Occasional Paper 7. Focus on the Global South, Bangkok.

Fuchs, D., 2007. Business Power in Global Governance. Lynne Rienner, Boulder.

Ganapati, S., Liu, L. 2009. Sustainable development in the Clean Development Mechanism: The role of designated national authority in China and India. Journal of Environmental Planning and Management, 52(1), 43-60.

Geels, F. W., 2005. Technological Transitions and System Innovations: A CoEvolutionary and Socio-Technical Analysis. Edward Elgar, Cheltenham. 
Green, J., 2008. Delegation and accountability in the Clean Development

Mechanism: The new authority of non-state actors. Journal of International Law and International Relations 4(2), 21-55.

Gupta, D., 2010. Valedictory address, presented at The India Carbon Market Conclave 2010, New Delhi, India, 9 September.

GTZ, 2006. Capacity Development for the Clean Development Mechanism: Lessons Learned in Ghana, India, Indonesia, South Africa and Tunisia. Frankfurt: GTZ Hamilton, K., 2009. Unlocking finance for clean energy: The need for 'investment grade' policy. Chatham House Briefing Paper, December. Chatham House, London

Hultman, N.E., Pulver, S., Guimarães, L., Deshmukh, R., Kane, J., 2012. Carbon market risks and rewards: Firm perceptions of CDM investment decisions in Brazil and India. Energy Policy 40, 90-102.

IEA, 2007. World Energy Outlook 2007. India and China. IEA, Paris.

IEA, 2010. Energy Poverty: How to Make Modern Energy Access Universal? Special Early Excerpt of the World Energy Outlook 2010 for the UN General Assembly on the Millenium Development Goals. IEA, Paris.

IFC (2008) Tata Ultra Mega - Summary of Proposed Investment. Available at: www.ifc.org/ifcext/spiwebsite1.nsf/0/EAB8E042D643A6EC852576BA000E2 B15, accessed 21 July 2011.

Joseph, K., 2010. The politics of power: Electricity reform in India. Energy Policy, $38(1), 503-511$.

Kadakia, S., Acharya. M., 2010. Quenching India’s green power thirst. Environmental Finance, May, 14-15. 
Knight, Z., Robins, N., Clover, R., Saravanan, D., 2011. Climate Investment Update. 13 January. HSBC Global Research, London

Krey, M., 2005. Transaction costs of unilateral CDM projects in India - results from an empirical survey. Energy Policy, 33(18), 2385-2397.

Lazarus, M., Chandler, C., 2011. Can concerns with CDM coal power projects be addressed through revisions to the ACM0013 methodology? SEI Briefing Note, December. Stockholm Environment Institute, Seattle.

Lema, A., Lema, R., in press. Technology transfer in the clean development mechanism: Insights from wind power. Global Environmental Change. http://dx.doi.org/10.1016/j.gloenvcha.2012.10.010

Levy, D., Newell, P., 2002. Business strategy and international environmental governance: toward a neo-Gramscian synthesis. Global Environmental Politics, 3(4), 84-101.

Lovell, H., MacKenzie, D., 2011. Accounting for carbon: the role of accounting professional organisations in governing climate change. In: P Newell, M Boykoff and E Boyd (eds) The New Carbon Economy: Constitution, Governance and Contestation. Wiley Blackwell, Oxford. 107-135.

Mahalingham, S., Jairaj, B., Citizen Consumer and Civic Action Group, Reddy, M.T., Kumar, S., Kumar, R., 2006. Electricity Sector Governance in India: An Analysis of Institutions and Practice. Prayas Energy Group and WRI, New Delhi and Washington.

Meadowcroft, J., 2009. What about the politics? Sustainable development, transition management, and long term energy transitions, Policy Sciences, 42, 323-340. 
Michaelowa, A., 2007. Unilateral CDM: Can developing countries finance generation of greenhouse gas emission credits on their own? International Environmental Agreements: Politics, Law and Economics, 7(1), 17-34.

Michaelowa, K., Michaelowa, A., 2011. India in the international climate negotiations: from traditional nay-sayer to dynamic broker, CIS Working Paper 70/2011. Climate Strategies, Cambridge.

Michaelowa, A., Purohit, P., 2007. Additionality determination of Indian CDM projects: Can Indian CDM project developers outwit the CDM Executive Board? Climate Strategies Discussion Paper CDM-1. Climate Strategies, Cambridge.

Michel, D., Pandya, A., 2009. Indian Climate Policy: Choices and Challenges. Henry L. Stimson Center, Washington DC.

MNRE, 2010. Renewable Energy in India: Progress, Vision and Strategy. Paper presented at the Delhi International Renewable Energy Conference (DIREC) 2010, New Delhi, 27-29 October.

MNRE, 2013. Renewable Energy Contributes 12.5\% in Total Power Generation. [online]. [Accessed 4 April 2013]. Available from: http://pib.nic.in/newsite/erelease.aspx?relid=93913 [Press release].

MoEF, 2009a. India's GHG Emissions Profile: The Result of Five Climate Modeling Studies. Government of India, Delhi

MoEF, 2009b. Climate Change Negotiations: India's Submissions to the United Nations Framework Convention on Climate Change. Government of India, Delhi.

MoEF, 2010. India: Greenhouse Gas Emissions 2007. Indian National Network for Climate Change Assessment and MoEF, Delhi. 
Narain, S., 2011. Fix growth, not environment. Times of India, 18 February.

Newell, P., Jenner, N., Baker, L., 2009. Governing clean development: A framework for analysis. Development Policy Review, 27(6), 717 - 739.

Planning Commission, 2006. Integrated Energy Policy: Report of the Expert Committee. Government of India, Delhi.

Planning Commission, 2010. Union Budget 2010-2011. Government of India, Delhi.

Politi, J., 2013. US Complains over Indian Solar Trade. Financial Times, 6 February.

Pulver, S., Benney, T., 2010. Climate governance through carbon markets in Brazil and India. Paper prepared for Transnational Governance: Transforming Global Environmental Politics? Workshop, Durham University, Durham, UK, 27-28 September.

Purohit, P., Michaelowa, A., 2008. CDM Potential of Solar Water Heating Systems in India. Solar Energy, 82(9), 799-811.

Ramesh, J., 2010. The two cultures revisited: The environment-development debate in India. Economic \& Political Weekly, XLV(42), 16 October.

Rao, K., Kishore, V., 2009. Wind power technology diffusion analysis in selected states of India. Renewable Energy, 34(4), 983-988.

Scarse, I., Smith A., 2009. The non-politics of managing low carbon socio-technical transitions. Environmental Politics, 18(5), 707-726.

Sethi, N., 2008. India refuses World Bank aid to fight climate change, Times of India, 10 October.

Sirohi, S., 2007. CDM: Is it a 'win-win' strategy for rural poverty alleviation in India? Climatic Change, 84, 91-110. 
Streck, C. 2004. New partnerships in global environmental policy: The Clean Development Mechanism. Journal of Environment and Development, 13(3), 295-322.

Verbong, G,, Loorbach, D. (eds), 2012. Governing the Energy Transition: Reality, Illusion or Necessity? Routledge, London.

World Bank, 2009. World Development Report 2010: Climate Change and Development. World Bank Group, Washington DC.

\footnotetext{
${ }^{1}$ In this paper we consider energy generation defined as 'clean' through the CDM and through various aspects of Indian energy policy, while recognising that definitions of clean energy are contested (Newell et al. 2009).
}

${ }^{2}$ The paper is based on 36 semi-structured interviews and a series of meetings during September 2010 with a range of Delhi-based policy makers and bureaucrats in relevant government ministries and authorities, project developers, consultants, private foundations, financiers, representatives of various bilateral and multilateral donors, and representatives of non-governmental organisations and civil society (Appendix 1). Interviewee data has been triangulated prior to interpretation in order to assess the validity of claims.

${ }^{3}$ Authors' interview with Member Secretary of DNA, MOEF, New Delhi, September 2010

${ }^{4}$ Authors' interview with GIZ representative, India Carbon Market Conclave 2010, New Delhi, September 2010 .

${ }^{5}$ Authors' interviews with a carbon market services consultant; and with a Director, MNRE, New Delhi, September 2010.

${ }^{6}$ Both ADB and IFC are providing $\$ 450 \mathrm{~m}$ of debt finance to the project, with IFC providing a further $\$ 50 \mathrm{~m}$ in equity.

${ }^{7}$ In addition to the REC scheme, the most significant of these is the Perform, Achieve and Trade (PAT) scheme for trade in energy efficiency measures, which came into force during August 2012. Pilot schemes are also planned for the introduction of domestic trade in sulphur- and nitrogen-based industrial air pollutants (Singh 2011). 
${ }^{8}$ Authors' interviews with private, public and third sector project developers, New Delhi, September 2010.

${ }^{9}$ Authors' interviews with carbon market consultants and project developers, New Delhi, September 2010.

${ }^{10}$ Authors' interview with Member Secretary of the DNA, MoEF, New Delhi, September 2010

${ }^{11}$ Authors' interviews with carbon market consultants and project developers, New Delhi, September 2010.

${ }^{12}$ Authors' interviews with Programme Manager, Gold Standard Foundation, New Delhi; Project Developers, Carbon Market Conclave 2010, New Delhi; Senior Program Officer of an international NGO and former staff member in the Maharashtra State Government, Gurgaon, September 2010.

${ }^{13}$ We thank an anonymous reviewer for highlighting this point.

${ }^{14}$ Authors' interview with Senior Program Officer of an international NGO and former staff member in the Maharashtra State Government, Gurgaon, September 2010.

${ }^{15}$ Authors' interview with Senior Program Officer of an international NGO and former staff member in the Maharashtra State Government, Gurgaon, September 2010.

${ }^{16}$ Authors' Interview with Senior Climate Finance Advisor, DfID, New Delhi, September 2011.

${ }^{17}$ Gram Sabha is a village assembly open to all citizens.

${ }^{18}$ Authors' interview with Deputy Marketing Manager, Suzlon, New Delhi, September 2010.

${ }^{19}$ Authors' interview with senior staff member, Social, Environment and Water Resources

Management Unit, World Bank, New Delhi, September 2010.

${ }^{20}$ The MNRE cites Central Electricity Regulatory Commission (CERC) data that suggests that India's target of 15 per cent of renewable energy in the electricity mix can be met without additional costs to the end-user, with additional costs borne by state electricity utilities (Gupta 2010).

${ }^{21}$ A $\$ 1.1$ per tonne tax was placed on coal in the 2010 budget.

${ }^{22}$ Authors' interview with Director, MNRE, New Delhi, September 2010.

${ }^{23}$ Interview with Director of MNRE, New Delhi, September 2010

${ }^{24}$ Interview with Director in the Ministry of Power, New Delhi, September 2010

\section{Appendix 1 - List of interviewee institutions}


Ministry of Environment and Forests (MoEF)

CDM Designated National Authority (DNA), MoEF

Ministry of New and Renewable Energy (MNRE)

Planning Commission

Central Electricity Authority (CEA)

former staff of Maharashtra State government

Ministry of Power

Bureau of Energy Efficiency (BEE), Ministry of Power

Former international climate change negotiator for Indian delegation

Carbon market consultants

Suzlon

Project developers - public, private and third sector

Confederation of Indian Industry (CII)

Federation of Indian Chambers of Commerce and Industry (FICCI)

Gold Standard Foundation

Centre for Science and Environment

Winrock International

The Energy and Resources Institute (TERI)

Centre for Policy Research (CPR)

Integrated Research and Action for Development (IRADe)

WWF

Research for Information System for Developing Countries (RIS)

GTZ (now GIZ)

UK Department for International Development (DfID)

World Bank: Social, Environment and Water Resources Management Unit, 
Renewable Energy and Energy Efficiency Partnership (REEEP) 